\title{
Sinergitas Pemilihan Presiden 2009 dengan Sistem Presidensialisme Murni dan Konsolidasi Demokrasi di Indonesia
}

\author{
Agus Riewanto \\ Sekolah Tinggi Agama Islam Negeri (STAIN) \\ agus_riewanto@yahoo.com
}

2009 is the second period of Direct Presidential Election after the first election in 2004. The Presidential Election of 2004 was considered as the eve of the new constitutional history of Indonesia, because by the direct election would strengthen pure presidential system based on the Constitution of 1945 post amendment, and at the same time would also consolidate democracy. In fact, however, during his tenure, the Elect President and his presidential institution have been facing strong current resistance in the Parliament, and this has been weakening consolidation of democracy. The main cause is the presence of multiparty which is not compatible with the pure system of presidential, in which president should be stronger or at least balanced with the position of parliament. Thus, Indonesian practice of constitutionalism since 2004 has been reflecting a parliamentary system. The Presidential Election of 2009 should synergetic with the pure presidential, and at once end the transition of democracy toward the consolidation of democracy.

Keywords: direct election, presidential, consolidate, democracy.

\section{Pendahuluan}

$\mathrm{B}^{\mathrm{a}}$ abakan sejarah demokrasi Indonesia mengalami perkembangan yang luar biasa pasca tumbangnya rezim Soeharto dari singgasana kepresidenan pada $21 \mathrm{Mei}$ 1998. Sejak itu, sejumlah peristiwa politik dan hukum menandai transisi menuju demokrasi di Indonesia. Salah satunya adalah penyelenggaraan Pemilu 1999 di bawah Presiden B.J. Habibie sebagai tonggak berawalnya transisi demokrasi. Hasil Pemilu 1999 melahirkan kelembagaan perwakilan rakyat (MPR) kemudian melanjutkan agenda demokratisasi ini melalui amandemen Undang-Undang Dasar (UUD) 1945.

Sejak amandemen konstitusi (UUD 1945) yang secara tegas meneguhkan eksistensi kedaulatan rakyat sebagai prinsip umum demokrasi, implementasi ke dalam pasal-pasal UUD 1945 hasil amandemen juga turut menyertainya. Nomenklatur tentang pemilihan umum (pemilu) sebagai aspek demokratisasi menjadi hal baru dalam khazanah konstitusi Indonesia.

Eksperimentasi penguatan ide kedaulatan rakyat ini selanjutnya dibuktikan melalui penyelenggaraan Pemilu 2004 lalu. Pemilu 2004 dikenal dengan jargonnya "Pemilu 2004 Beda" memang terbukti. Perbedaan pemilu 2004 dengan pemilu-pemilu sebelumnya di antaranya adalah munculnya Komisi Pemilihan Umum (KPU) sebagai lembaga penyelenggara pemilu yang independen, nasional dan tetap; pemilihan langsung oleh pemilih dengan cara mencoblos nama calon legislatif; adanya daerah pemilihan sebagai wujud pertanggungjawaban publik para legislator kepada konstituen secara lebih jelas; dan 
Sinergitas Pemilihan Presiden 2009...; Agus Riewanto

yang membedakan dengan pemilu terdahulu adalah dilaksanakannya pemilihan Presiden dan Wakil Presiden secara langsung oleh rakyat pemilih. Eksperimentasi politik ini mengambarkan bahwa partisipasi politik publik telah benar-benar menjadi penentu dalam pengisian jabatan publik di Indonesia.

Berdasarkan pemikiran itu, pertanyaannya adalah apakah pemilihan presiden dan wakil presiden tahun 2004 lalu telah mampu menjadikan titik pijak bagi pemantapan konsolidasi demokrasi ? Apa kelemahan dan kekurangan dari pelaksanaan Pilpres 2004 lalu ? Desain apa yang diperlukan agar Pilpres 2009 dapat bersinergi dengan agenda pemantapan konsolidasi demokrasi ?. Sejumlah pertanyaan itu akan dieksplorasi lebih jauh dalam tulisan ini.

Melacak Teori Pemilu-Konsolidasi Demokrasi dan Sistem Presidensialisme Samuel Huntington (1995) dalam studinya "gelombang demokratisasi ketiga" menggambarkan, bahwa demokratisasi pada tingkatan yang paling sederhana mensyaratkan terjadinya tiga hal, yaitu (1) berakhirnya sebuah rezim otoriter; (2) dibangunnya sebuah rezim demokratis; (3) pengkonsolidasian rezim demokratis itu.

Alfred Stepan (1993,104-143) menyebutkan bahwa transisi demokrasi dari rezim otoriter ada tiga model kemungkinan : (1) penjajahan dari luar dan peperangan internal; (2) tranformasi internal dari elit rezim otoriter menuju rezim demokratis; (3) kekuatan internal kelompok oposisi yang menumbangkan kekuasaan otoriter yang berkuasa.

Sementara Samuel Huntington menyebutkan, bahwa ada tiga kemungkinan model demokratisasi, yaitu (1) transformasi (reforma), yaitu demokratisasi terjadi ketika elit yang berkuasa mempelopori proses perwujudan demokrasi. (2) Replacement (ruptura), yaitu demokratisasi terjadi ketika kelompok oposisi mempelopori proses perwujudan demokrasi, dan rezim otoriter tumbang atau digulingkan. (3) Trans-placement (ruptforma), yaitu demokratisasi terjadi sebagai sebuah hasil tindakan bersama antara kelompok pemerintah dan kelompok oposisi.

Dengan demikian, demokratisasi memiliki dua aspek, yaitu transisi demokrasi dan konsolidasi demokrasi (Giuseppe di Palma, 1997). Transisi demokrasi adalah titik awal antara rezim otoritarian dengan rezim demokratis. Transisi dimulai dari keruntuhan rezim otoritarian lama, yang kemudian diikuti atau berakhir dengan pengesahan lembaga-lembaga politik dan aturan politik baru di bawah payung demokrasi.Proses konsolidasi demokrasi mencakup peningkatan secara prinsipil komitmen seluruh elemen masyarakat pada aturan main demokrasi (Laurence Whitehead, 1989:30).

Konsolidasi demokrasi juga dipahami sebagai sebuah proses panjang yang mengurangi kemungkinan pembalikan demokratisasi, mencegah erosi demokrasi, menghindari keruntuhan demokrasi, yang diteruskan dengan melengkapi demokrasi, pendalaman demokrasi dan mengorganisir demokrasi secara berkelanjutan (Andreas Schedler, 1998).

Masing-masing tahapan tidak dapat dipisahkan (continue) antara satu tahap dengan tahap yang lain. Karena itu, biasanya tahap transisi demokrasi mensyaratkan diskontinuitas dengan tahap otoriter-totaliter yang antidemokrasi, sedangkan tahap sistem otentik demokrasi mensyaratkan kontinyuitas dengan transisi demokrasi.

Untuk konteks Indonesia tampaknya meleset dari teori itu. Lihatlah faktanya, hari- 
UNISIA, Vol. XXXI No. 70 Desember 2008

hari ini kita belum dapat memutus hubungan (discontinuitas) dengan sistem negara Orba dan berikut sifat-sifat buruknya. Karena itu transisi demokrasi yang tengah kita jalani saat ini menjadi begitu lamban dan terhambat. Padahal jika kita hendak mewujudkan cita-cita otentik demokrasi (Indonesia baru) mensyaratkan kontinyuitas transisi demokrasi. Kalau transisi demokrasinya saja belum bisa melepaskan diri dari penjara dan sifat sistem buruk negara Orba dan lamban, pastilah beban menuju otentik demokrasi (Indonesia baru) tak akan pernah kunjung tiba.

Mengapa transisi demokrasi kita begitu lamban dan terhambat? Tak lain karena bekerjanya sistem politik-demokrasi kita selama ini (1998-2008) berhenti di tingkat prosedural. Praktik politik demokrasi kita terjebak dalam prosedur dengan melupakan substansi.

Kita disibukkan dengan aneka pesta politik-demokrasi, misalnya: menjamurnya pendirian partai politik (1998) dan pemilu dipercepat (1999), amandemen I-IV UUD 1945 (1999-2002), membentuk puluhan komisi kuasi negara (1999-2006), perubahan sistem pemilu DPR-DPRD dari proporsional tertutup ke proporsional terbuka (2004), Pilpres secara langsung (2004) dan Pilkada langsung (2005-2008). Namun aneka perubahan dan bentuk politikdemokrasi itu hanya berhenti di tingkat prosedural-mekanistik dan lupa dengan isi.

Nyatanya kehidupan sosial-ekonomi rakyat tak lebih baik dari era Orba, kendati dipimpin oleh para aktor politik yang mematuhi dan mentaati aneka perubahan sistem politik demokrasi dan hukum hasil amandemen UUD 1945 itu. Perhatikanlah, jumlah kemiskinan kian menjulang tinggi, angka pengangguran melangit, korupsi merajalela, elite politik sibuk memburu kekuasaan dan pundi-pundi uang. Demokrasi hanya menjadi ajang money politics. Karena itu, demokrasi kita tak pernah lepas dari konflik dan anarki, sekadar menjadi lips service, pentas mengobral janji tanpa realisasi.

Wajarlah bila akhir-akhir ini banyak rakyat kita yang mengugat praktek politikdemokrasi era reformasi ini. Kita pun tak jarang menyaksikan bagaimana rakyat selalu membandingkan Orde Reformasi dengan nostalgia Orba.

Siapapun tahu mekanisme politikdemokrasi penting, tetapi esensinya tidak boleh diabaikan. Kita selama ini seolah-olah memaknai demokrasi sebatas representasi hak-hak sipil dan politik (civil and political rights) sehingga demokrasi dijauhkan dari hak-hak dasar manusia lain (HAM), yakni hak-hak ekonomi dan hak-hak sosial (social and economics rights). Yang terjadi kemudian adalah ketimpangan dan antagonisme. Yang kaya makin kaya, yang miskin makin sekarat, yang berkuasa makin menumpuk dan menambah, yang tak berkuasa memburunya dengan tanpa mengindahkan moral dan etika. Itulah fakta politik-demokrasi yang kita lihat sepanjang tahun 1998-2008 ini (Agus Riewanto, 2007).

Fenomena itu mengajarkan pada kita, bahwa 9 (sembilan) tahun perjalanan transisi demokrasi menuju otentik demokrasi (Indonesia baru) hanya ilusi belaka. Bahkan nyaris hanyalah pergantian simbol, bukan pergantian subtansi. Kesalahan utama kita adalah menyerahkan urusan pemerintahan dan negara pada "aktor lama berbaju baru" (politisi didikan Orba, pura-pura bermental reformis) dan "aktor baru bermental lama" (politisi didikan reformasi, bermental Orba). Tanpa seleksi dan kontrak politik yang jelas.

Secara konstitusional, negara kita berdasarkan atas hukum yang demokratis 
Sinergitas Pemilihan Presiden 2009...; Agus Riewanto

(constitusional democracy atau democratische rechtstaat). Di dalamnya menganut supremasi konstitusi. Konstitusi sebagai hukum dasar tertinggi dalam kehidupan berbangsa dan bernegara antara lain mengatur mengenai aspek-aspek mendasar kenegaraan, seperti prinsip negara hukum dan demokrasi (rule of law), tujuan dan cita-cita bernegara (staatsidee), pemisahan kekuasaan (separation of power), hak dan wewenang lembaga negara, hubungan antarlembaga negara (check and balances), sistem pemerintahan, dan prinsip-prinsip dasar hak asasi manusia (human rights).

Baik sebelum maupun sesudah perubahan, UUD 1945 menganut sistem pemerintahan presidensial. Menurut kategori CF Strong, sistem presidensial memiliki ciriciri, pertama, pemilihan presiden secara langsung (direct mandate). Kedua, presiden sebagai kepala negara sekaligus kepala pemerintahan. Ketiga, presiden berhak mengangkat dan memberhentikan menteri negara. Keempat, masa jabatan presiden tetap (fix term). Kelima, presiden dapat dijatuhkan hanya karena alasan hukum, bukan alasan politik. Sistem ini menjamin adanya stabilitas pemerintahan, karena posisi presiden kuat di hadapan konstitusi (CF Strong, 1966).

Namun demikian, sistem presidensial juga mengandung risiko legal maupun politik. Sebagaimana banyak terjadi di berbagai negara yang menganut sistem ini, Indonesia juga mengalaminya. Sejumlah risiko terkait implementasi sistem pemerintahan presidensial timbul bukan hanya karena regime type, tetapi juga karena kelemahan atau krisis institusional dan krisis konstitusional. Implementasi pemerintahan presidensial menurut UUD 1945 sebelum perubahan periode tahun
1999-2002, Republik Indonesia selalu mengalami sejumlah risiko.

Risiko-risiko itu, pertama, kecenderungan otoriter dan terciptanya negarakekuasaan (rule by decree), maklumat, penpres, surat perintah, pada periode 19451949, 1959, 1966; dan sulit merealisasikan negara-hukum (rechtstaat). Kedua, legitimasi pemerintahan negara bukan melalui mekanisme consent by the governed atau berupa direct mandate. Ketiga, timbul kerancuan konstitusional dan institusional pemerintahan negara periode 1959-1966. Misalnya, penetapan dan keputusan presiden menjadi dasar "konstitusional" pemerintahan negara dan pembentukan lembaga-lembaga negara setelah Dekrit 5 Juli tahun 1959.

Keempat, krisis politik dan sulitnya melakukan suksesi kepala negara dan kepala pemerintahan 1945-1966 dan 19661998. Kelima, kontrol ketat oleh pemerintah terhadap sistem demokrasi perwakilan melalui pemaksaan fusi Partai, mekanisme recall, litsus, kontrol kebebasan pers. Keenam, constitutional crisis dan extra-constitutional manouvers berupa maklumat, dekrit, penpres, kepres yang menimbulkan korupsi politik. Ketujuh, pemerintahan negara mampu mempertahankan negaramerdeka, bersatu, dan berdaulat, namun belum mencapai negara-adil dan negaramakmur. Kedelapan, lemahnya perlindungan HAM, baik hak politik maupun ekonomi, sosial dan budaya.

Kelemahan dan risiko tersebut terjadi karena UUD 1945 sebelum perubahan, telah diperbaiki dengan UUD hasil perubahan yang telah memenuhi syarat-syarat ideal konstitusi modern. Pertama, legitimasi konstitusi berdasarkan suatu konsensus lebih luas dari rakyat atau konvensi-konvensi wakil rakyat. Kedua, mengakui dan 
UNISIA, Vol. XXXI No. 70 Desember 2008

melindungi hak-hak dasar rakyat. Ketiga, sistem pemilu dan direct mandate untuk kekuasaan pemerintahan negara. Keempat, kesetaraan lembaga negara. Kelima, memilah, mengecek dan menyeimbangkan hak, tanggungjawab, kewenangan, dan kemampuan lembaga-lembaga negara (separation of powers, checks and balances, self-regulatings).

Keenam, memiliki sistem tanggung jawab pemerintahan negara (lines of accountability). Ketujuh, independensi kekuasaan kehakiman dan mahkamah konstitusi. Kedelapan, menetapkan fixedterms untuk masa jabatan pemegang kekuasaan pemerintahan negara. Institusional Type merupakan suatu sistem pemerintahan presidensial seperti rule of rotation melalui sistem pemilu, akuntabilitas pemerintahan, mekanisme pemisahan kekuasaan, checks and balances, independensi komisi pemilihan umum, mekanisme judicial review, impeachment, equality of power masing-masing lembaga pemerintahan negara, dan melalui sistem kepartaian sangat menentukan level risiko dari setiap implementasi sistem pemerintahan presidensial.

Pentingnya faktor-faktor kelembagaan tipe-tipe rezim untuk menganalisis dampaknya terhadap variabel perantara, yakni konsolidasi demokrasi dan risikorisiko sistem pemerintahan presidensial. Variabel-variabel kelembagaan mencakup pula sistem kepartaian, lines of accountability, checks and balances, sistem pemilu, judicial review, efektivitas pemerintah, pembuatan keputusan, good governance.

Model konstitusional dan institusional pemerintahan presidensial Republik Indonesia menurut UUD 1945 sesudah perubahan periode tahun 1999-2002 mirip sistem pemerintahan presidensial AS. Seperti, pertama, pemilihan langsung presiden-wakil presiden dan wakil rakyat. Kedua, presiden adalah kepala negara dan kepala pemerintahan.

Ketiga, ada mekanisme checks and balances dan separation of powers di antara lembaga negara. Keempat, mengakui hakhak dasar warga negara. Kelima, sistem pemilu regular. Keenam, tanggung jawab pemerintahan negara kepada pemilih dan konstitusi. Ketujuh, mekanisme judicial review. Ke delapan, mekanisme impeachment. Kesembilan, equality of branches.

\section{Kajian Pustaka}

\section{Pilpres 2004 Pijakan Pemantapan Konsolidasi Demokrasi}

Terwujudnya keinginan untuk melakukan amandemen UUD 1945 adalah salah satu indikasi dari transisi demokrasi ke konsolidasi demokrasi. Adapun bentuk hukum amandemen terhadap konstitusi UUD 1945 dilakukan mulai Sidang Umum MPR 1999, Sidang Tahunan MPR 2000, Sidang Tahunan MPR 2001, Sidang Tahunan 2002, yang menghasilkan "Perubahan Pertama, Kedua, Ketiga dan Keempat UUD Negara RI 1945". Secara spesifik, amandemen konstitusi Indonesia menghasilkan sejumlah design baru format kenegaraan sebagai berikut (Jimly Asshiddiqie, 2005).

Pertama, Presiden dan Wakil Presiden dipilih melalui pemilu secara langsung oleh rakyat (direct popular vote), sedangkan kewenangan MPR hanya sebatas melantik Presiden dan Wakil Presiden terpilih saja (Afan Gaffar, 2002: 435-439). Sebagai konsekuensinya, berbeda dengan sebelum perubahan UUD 1945, Presiden tidak lagi bertanggung jawab kepada MPR, namun bertanggung jawab langsung kepada rakyat 
Sinergitas Pemilihan Presiden 2009...; Agus Riewanto

pemilih (direct responsible to the people). Hal ini berbeda dengan sistem pemerintahan sebelum perubahan UUD 1945, di mana kedaulatan rakyat dilakukan sepenuhnya oleh MPR, dan kini kedaulatan rakyat tetap di tangan rakyat. Sebagai konsekuensinya adalah jabatan Presiden dan Wakil Presiden, anggota DPR dan DPD yang keduanya merupakan anggota MPR, dipilih secara langsung oleh rakyat melalui pemilu. Dengan demikian, masing-masing lembaga negara sama-sama memiliki legitimasi politik yang kuat, dan masing-masing bertanggung jawab langsung kepada pemegang kedaulatan asli yaitu rakyat (I Made Leo Wiratma, 2002).

Kedua, kedaulatan rakyat dilaksanakan oleh berbagai lembaga negara sesuai dengan bidang tugasnya masing-masing menurut konstitusi UUD 1945. (Ramlan Surbakti, 2002). Hal ini terlihat dari adanya pembagian tugas masing-masing lembaga negara yang makin jelas dan terperinci, sehingga menghindari terjadinya tumpang tindih dan intervensi kewenangan antar lembaga negara (separation of power). Presiden memegang kekuasaan menjalankan pemerintahan, DPR dan DPD dapat mengawasi jalannya pemerintahan yang dilaksanakan oleh Presiden dan kabinetnya, dan lembaga peradilan dalam hal ini Mahkamah Agung dan Mahkamah Konstitusi memiliki wewenang melakukan kontrol yuridis lewat judicial review terhadap kebijakan yang diambil oleh Presiden sebagai pemegang kekuasaan eksekutif, maupun terhadap kebijakan yang dibuat oleh DPR berupa produk undang-undang. Kondisi ini mengarah kepada terciptanya situasi checks and balances antar lembaga negara yaitu eksekutif, legislatif dan yudisial.

Ketiga, adanya jaminan terciptanya stabilitas jalannya pemerintahan karena jabatan Presiden dibatasi dalam masa jabatan lima tahun, dan hanya dapat diberhentikan oleh MPR dalam kondisi tertentu saja berdasarkan UUD, serta melalui mekanisme hukum yaitu pembuktian hukum oleh Mahkamah Konstitusi (Leo Agustino, 2002). Dengan demikian Presiden tidak dapat diusulkan oleh DPR untuk diber-hentikan semata-mata karena alasan konflik politik. Demikian pula Presiden dilarang untuk membekukan dan/atau membubarkan DPR.

Amandemen konstitusi UUD 1945 membawa perubahan aliran pemikiran hukum dan politik yang dianut Indonesia. Sebelum perubahan UUD 1945, aliran pemikiran yang dianut lebih cenderung kepada teori kedaulatan negara. Hal ini terlihat dari digunakannya teori "negara integralistik" atau teori "negara organik" yang diajarkan oleh Spinoza, Adam Muller dan Hegel, kemudian staatsidee negara integralistik ini digunakan oleh Soepomo dalam penyusunan UUD 1945, ( Risalah Sidang BPUPKI-PPKI 29 Mei 1945 - 19 Agustus 1945: 27-28.) dan dalam perkembangannya teori negara integralistik ini digunakan sebagai tafsir historis atas model negara yang dianut oleh UUD 1945 selama era Orde Baru (Marsillam Simanjuntak, 1994).

Dengan kata lain, format amandemen UUD 1945 adalah dalam rangka mengubah haluan sistem pemerintahan dari quasi presidensial ke sistem presidensial murni. Definisi paling sederhana mengenai perbedaan antara sistem parlementer dan presidensial itu adalah tingkat independensi relatif eksekutif. Pada sistem presidensial, eksekutif relatif independen dari legislatif. Pada sistem parlementer, terdapat kesalingtergantungan dan kesalingterkaitan dalam kapasitas-kapasitas legislatif dan eksekutif (Arend Lipjhart, ed: 1992).

Menurut kategori CF Strong, sistem presidensial memiliki ciri-ciri, pertama, 
UNISIA, Vol. XXXI No. 70 Desember 2008

pemilihan presiden secara langsung (direct mandate). Kedua, presiden sebagai kepala negara sekaligus kepala pemerintahan. Ketiga, presiden berhak mengangkat dan memberhentikan menteri negara. Keempat, masa jabatan presiden tetap (fix term). Kelima, presiden dapat dijatuhkan hanya karena alasan hukum, bukan alasan politik. Sistem ini menjamin adanya stabilitas pemerintahan, karena posisi presiden kuat di hadapan konstitusi (C.F. Strong, 1952, Modern Political Constitutions: 146-148).

\section{Titik Lemah Pilpres 2004 dan Sinergitas Sistem Presidensialisme}

Tataran ide besar amandemen UUD 1945 yang memantapkan sistem presidensial murni diwujudkan benar dalam pratek demokrasi dengan penyelenggaraan Pilpres secara langsung pada tahun 2004. Walaupun kala itu, perdebatan akan perlu tidaknya Pilpres langsung sempat menyedot perhatian publik. Karena terdapat usul tentang pilpres dua putaran, putaran pertama dipilih rakyat dan putaran kedua dipilih MPR. Kendati akhirnya pilpres dapat berlangsung dengan pola dua putaran yang kesemuanya dipilih rakyat. (Agus Riewanto, 2002). Namun Pilpres 2004 yang berlangsung dua putaran, yakni putaran pertama 5 Juli 2004 dan putaran kedua 20 September 2004 ini tak serta-merta berjalan mulus karena disana-sini terdapat serangkaian kelemahan dalam pelaksanaannya. Yang dapat direkam sebagai berikut:

Pertama, tentang bagaimana UU No.23 Tahun 2003 tentang Pemilihan Presiden dan Wakil Presiden (UU Pilpres) dirumuskan di lembaga legislatif dan eksekutif. Problem yang amat menonjol kala itu, dan berakibat pada permasalahan lain yang amat mendasar adalah minimnya sosialisasi yang dilakukan kedua lembaga itu. Dibandingkan dengan tingkat urgensi UU tersebut, sosialisasi yang dilakukan amat kurang dilakukan dan dampaknya adalah minimnya masukan masyarakat atas UU bersangkutan dan selebihnya masyarakat sendiri lebih memahami bahwa UU tersebut lebih banyak merupakan buah kompromi yang amat elitis, sebuah kompromi politik tingkat tinggi.

Jelas bahwa dilihat dari prosesnya, UU Pilpres ini disebut sebagai hasil kompromi politik tingkat tinggi dari partai-partai besar yang masing-masing sudah memiliki calon presiden. Misalnya terkait dengan syarat Capres: Perlunya Sehat jasmani dan Rohani. (belakangan dimaksudkan untuk mengganjal Gus Dur dari pencalonan), Perlunya pendidikan Sarjana (belakangan dimaksudkan untuk mengganjal Megawati dan Gus Dur, walaupun akhirnya cukup berpendidikan SLTA), Dilarangnya calon yang pernah dihukum penjara maksimal 5 tahun (dimaksudkan untuk mempersulit Akbar Tanjung dalam Bursa Konvensi Partai golkar), dan lain-lain.

Kedua, mengenai isu-isu menjelang pemilu, yang belum bisa dikatakan sebagai isu yang produktif untuk merangsang partisipasi masyarakat dalam Pilpres 2004. Isu-isu menjelang pemilu sering terjebak pada isu yang elitis dan belum bisa mengungkapkan kebutuhan sesungguhnya dari masyarakat. Akibatnya isu yang lahir bukanlah cerminan visi, misi dan program perubahan sosial yang dibutuhkan masyarakat, melainkan masyarakat sering dijebak hanya untuk mendengar perdebatan tentang teknis penyelenggaraan pemilu. Padahal seharusnya isu menjelang pesta demokrasi hendaknya isu yang menyangkut visi perubahan.

Keempat, tentang koalisi politik yang dilakukan oleh para elit masih terjebak pada koalisi yang elitis. Koalisi kebangsaan ver- 
Sinergitas Pemilihan Presiden 2009...; Agus Riewanto

sus koalisi kerakyatan, misalnya, (dalam putaran kedua) tampak sebagai koalisi yang mengabaikan kepentingan rakyat. Koalisi sering hanya menghasilkan perpecahan partai, ketidakpuasan serta berbagai hal negatif lainnya. Itu menunjukkan bahwa koalisi yang elitis hanya ditujukan untuk kepentingan para elit-elit itu, mulai dari jatah kursi di kabinet sampai jatah bagaimana akses kue kekuasaan dicapai. Bukan berdasarkan pada kesamaan ideologi perjuangan partai maupun kesamaan visimisi antar parpol. Karena itu, koalisi parpol dalam menggusung pasangan Capres dan Cawapres Pilpres 2004 lalu hanya berkisar pada hitungan prakmatis untuk mencapai kemenangan dalam Pilpres.

Sehingga di dapatkan komposisi lima pasangan calon lima pasangan calon yang akan menjadi presiden dan wakil presiden pertama pilihan rakyat. Pasangan itu adalah Wiranto-Salahuddin Wahid, Megawati Soekarnoputri-Hasyim Muzadi (PDIP), Amien Rais-Siswono Yudo Husodo, Susilo Bambang Yudhoyono-Jusuf Kalla dan Hamzah Haz-AgumGumelar.

Kelima, dari semua tahapan Pilres 2004, yakni: (1) pemutakhiran data pemilih dan penyusunan daftar pemilih; (2) pendaftaran pasangan calon; (3) penetapan pasangan calon; (4) masa kampanye; (5) masa tenang; (6) pemungutan dan penghitungan suara dan (7) penetapan hasil pilpres. Relatif dapat berjalan sesuai jadwal.

Setidaknya dalam pelaksanaan tahapan Pilpres terdapat 3 (tiga) tahapan yang menuai sejumlah masalah, yakni: Daftar Pemilih Tetap (DPT), kampanye, dan pemungutan suara pilpres.

DPT Pilpres adalah hal pertama yang memperoleh protes publik terutama disebabkan oleh pemilih tidak terdaftar, daftar pemilih ganda, pemilih fiktif, pemilih di bawah usia, pemilih berstaus TNI/Polri dan pemilih meninggal dunia,sehingga berakibat adanya dugaan penggelembungan dan pengurangan suara calon tertentu.Walaupun pemungutan suara Pilpres 2004 jauh lebih sederhana dan mudah dibandingkan dengan pemilu legislatif 2004. Pemilih tak perlu lama antre di TPS. Waktu yang diperlukan antara penyerahan formulir Model C6 (Surat Pemberitahuan Waktu dan TPS) dan panggilan untuk mencoblos hanya dalam hitungan menit. Tak cuma itu, pemilih hanya membutuhkan waktu sekitar satu menit untuk membuka surat suara, mencoblos, dan memasukkan surat suara ke kotak suara.

\section{Singkatnya, pemungutan suara tak serumit pemilu legislatif.}

Meski tidak memerlukan banyak waktu, kesalahan-kesalahan teknis yang elementer masih terjadi. Misalnya, di beberapa TPS terjadi pencoblosan yang "menyeberangi" kotak pasangan calon. Misalnya, beberapa TPS di beberapa daerah di kawasan timur Indonesia, jumlah kesalahan pencoblosan hampir mencapai 100 surat suara. Sejauh ini kesalahan terjadi dalam tiga bentuk: (1) coblosan tembus ke kotak pasangan calon lain, (2) coblosan tembus sampai ke "halaman judul" surat suara, dan (3) meski amat terbatas, ada juga pemilih yang melakukan coblosan ganda dengan mencoblos lebih dari satu pasangan calon presiden dan wakil presiden.

Bila dicermati ketiga bentuk penyeberangan itu, semua kesalahan terjadi lebih karena kurangnya sosialisasi dan simulasi tentang tata cara pencoblosan. Guna mengantisipasi kesalahan itu, KPU mengeluarkan SK No 1151/15/VII/2004 yang menyatakan, surat suara yang dicoblos sehingga tembus sampai ke halaman judul 
tetap dinyatakan sah (SK KPU SK No 1151/ 15/VII/2004). Dengan SK itu, coblosan yang tembus ke pasangan lain dan yang melakukan coblosan ganda, pilihan rakyat tidak dapat diselamatkan. Akibat antisipasi darurat yang dilakukan KPU, beberapa TPS yang sudah menyatakan coblosan yang tembus ke halaman judul tidak sah harus melakukan penghitunganulang.

Kampanye Pilpres 2004 belum bisa dibandingkan dengan masa-masa sebelumnya, karena memang pilpres secara langsung baru pertama kali digelar. Namun mencatat dan menganalisis ikhwal kampanye Pilpres 2004, baik untuk putaran pertama maupun kedua, ada banyak sisi yang dipetik sebagai bahan pengalaman di masa mendatang. Model kampanye kita masih model "yang lalu" kendati ada banyak perubahan, misalnya dengan mulai dibidiknya televisi sebagai media terefektif menyedot simpati.

Yang menonjol dari kampanye Pilpres 2004 adalah pada upaya mobilisasi massa, arak-arakan massa dengan raungan kendaraan bermotor tak jarang menggunakan anak-anak di bawah umur sebagai maskot, mendatangkan artis-artis ibu kota, bagi-bagi kupon bensin, aneka makanan, uang partisipasi, kaos dan lain-lain.

Seperti diberitakan, TII mengeluarkan temuan tentang praktik politik uang dilakukan dengan berbagai cara, antara lain pembagian doorprize, pembagian uang bensin, pemberian beasiswa, dan pembagian barang lain seperti jam tangan dan kerudung. Pembagian uang bensin antara lain dilakukan di pasar Bantul, 4 Juni 2004, sebesar Rp 1.450.000. Sementara itu, pembagian beasiswa dilakukan di kampus Moh Merodji, Jember pada 5 Juni 2004. Pembagian jam tangan dilakukan di beberapa tempat di Jember (Kompas, 7 Juni 2006).
ICW melalui TII menyampaikan empat kegiatan yang terindikasi politik uang dari pasangan Megawati Soekarnoputri - Hasyim Muzadi, Hamzah Haz - Agum Gumelar, dan Wiranto-Salahuddin Wahid. Dari empat laporan ini, dua dugaan politik uang dilakukan oleh tim kampanye WirantoSalahuddin.

Cara-cara ini nyaris melupakan esensi kampanye, yakni untuk melihat dan menilai program kerja yang ditawarkan Capres. Apakah relevan dengan kepentingan dan pertautan dengan nasib masa depan rakyat. Namun karena derasnya mobilisasi massa yang dilakukan elit politik lokal yang tergabung dalam tim kampanye Capres, maka esensi kampanye nyaris kabur dan ajang kampanye hanyalah menjadi panggung hiburan publik, layaknya sebuah pesta.

Keenam, tentang pertarungan para kandidat menjadi catatan lain yang amat penting dikemukakan untuk memahami ada apa di balik peristiwa. Misalnya ada motif politik apa atas isu "VCD Banjarnegara", yang menggambarkan tak netralnya aparat Polri dari jebabakan politisasi. Kala itu, berbagai kalangan menuntut pengusutan tuntas kasus VCD rekaman pengarahan di Markas Kepolisian Resor Banjarnegara, Banyumas, yang diduga mendukung calon presiden Megawati Soekarnoputri. VCD rekaman itu memuat pemaparan Kepala Kepolisian wilayah (Kapolwil) Banyumas Komisaris Besar AF Mapparesa di Polres Banjarnegara. Rakaman yang kemudian disampaikan kepada umum oleh Ikatan Alumni Universitas Indonesia (lluni) tersebut isinya mengindikasikan bahwa jajaran Polri mendukung capres Megawati Soekarnoputri-Hasyim Muzadi.

Kejadian tersebut barangkali sedikit mengejutkan, karena selama ini, mengenai 
netralitas pemilihan umum (pemilu) yang seringkali disorot adalah TNI. Jarang perhatian ditujukan kepada Polri. Padahal, sebagai entitas yang sudah mandiri, Polri bagi peserta pemilu juga sama menariknya dengan TNI untuk ditarik-tarik ke dalam ranah politik praktis, terutama dalam memberikan sumbangan suara yang signifikan (Kompas, 27 Juli 2004).

Begitu pula di berbagai daerah para bupati/walikota banyak memanfaatkan fasilitas negara dan mendorong aparat birokrasi untuk memilih salah satu Capres. Titik puncaknya adalah kejadian penggelembungan suara untuk salah satu calon di"Ponpes al-Zaytun". Selalu ada makna di balik peristiwa. Sayang, kala itu media massa jarang yang membeberkan makna. Media massa sering hanya mengungkap fakta.

\section{Inkonsistensi Sistem Presidensialisme}

Tentang harapan rakyat atas presiden dan wakil presiden terpilih SBY-JK yang tak terwujud. Secara singkat, pokok program kerja SBY-JK dalam lima tahun adalah mewujudkan Indonesia yang aman dan damai, mewujudkan masyarakat yang adil dan demokratis, serta mewujudkan masyarakat yang lebih sejahtera. Apakah itu sudah terwujud?

Tercermin dalam pemberitaan media massa, menganggap kinerja SBY-JK masih jauh dari harapan. Sebagian menganggap kegagalan SBY-JK disebabkan gaya kepemimpinan SBY yang kurang tegas, terlalu hati-hati, dan sebagainya. Lebih dari itu disebabkan oleh terutama sistem pemerintahan yang rancu.

Secara konstitusional ia adalah pemerintahan presidensial, tetapi dalam praktik penyelenggaraannya adalah sistem parlementer. Kerancuan sistem menyebabkan Yudhoyono tidak berdaya menyusun kabinet secara mandiri karena harus mengakomodasi kepentingan partai politik untuk menghindari konflik dengan DPR. Oleh sebab itu, dari 38 anggota kabinet, 19 menteri berasal dari delapan partai politik. Kalau akomodasi partai dalam kabinet direfleksikan dalam kekuatan di DPR, partai yang ikut memerintah sebanyak 404 kursi (sekitar 73 persen) dan di luar pemerintah 146 kursi (sekitar 23 persen).

Melihat konstruksi kekuasaan tersebut, sebenarnya pemerintahan SBY-JK adalah pemerintahan kolektif yang lemah dan rawan konflik kepentingan dan dapat mengancam kelangsungan pemerintahan. Konflik kepentingan bahkan mungkin terjadi antara Presiden dan Wakil Presiden. Oleh sebab itu, energi pemerintahan SBY-JK, selain terkuras untuk menjaga hubungan dengan partai politik yang duduk dalam kabinetnya agar tetap harmonis, juga terforsir untuk memelihara duet mereka (Agus Riewanto, 2007).

Dari segi koherensi sistem pemerintahan yang dianut dalam amandemen UUD 1945 adalah presidensial murni namun berkombinasi dengan sistem multipartai. Inilah yang mengakibatkan dinamika ketatanegaraan Indonesia dewasa ini cenderung ditandai oleh perebutan dukungan suara di DPR yang terkesan mengedepankan kepentingan semata. Sistem multipartai telah menghasilkan pemerintahan dengan dukungan minoritas di parlemen yang dapat mengakibatkan perseteruan berkepanjangan antara presiden dan parlemen serta menyebabkan instabilitas pemerintah (Aidil Firiciada Azhari: 2008). Kekuasaan lembaga tinggi negara di Indonesia mengalami pergeseran posisi 
UNISIA, Vol. XXXI No. 70 Desember 2008

dari waktu ke waktu. Dinamika ketatanegaraan mempengaruhi pergeseran posisi tersebut. Bandul kekuasaan lembaga tinggi negara itu berayun dari executive heavy (1968-1998), dan kini ke legislative heavy (1998-2008) (Munafrizal Manan, "Bandul Kekuasaan Negara”, Koran Tempo, 26 Agustus 2008).

Singkatnya, banyak hal yang sebelumnya dapat diputuskan sendiri oleh presiden menjadi harus mendapatkan persetujuan DPR. Pola kekuasaan seperti ini merupakan wujud berlakunya legislative heavy.

\section{Pembahasan}

Agar Pilpres 2009 mendatang lebih demokratis bukan saja dalam konteks prosedure tapi juga substansi, yakni menghasilkan presiden dan wakil presiden yang legitimate di mata rakyat dan menuju efektifitas pemerintahan sistem presidensial yang koheren dengan agenda memantapkan konsolidasi demokrasi,maka diperlukan sejumlah skenario menambal kekurangan sistem Pilpres 2004 lalu mendesain sistem Pilpres 2009 yang lebih baik. Ihtiar berikut ini adalah jawaban atas pernyataan itu.

\section{Desain UU Pilpres 2009 yang Elegan}

Prasyarat penting bagi penyelenggaraan Pilpres 2009 agar lebih demokratis dimulai dengan perlunya desain UU Pilpres yang kian menjauh dari sikap kompromistis antar elite yang berujung pada pemihakan atas kepentingan kelompok dan partai politiknya ketimbang kepentingan jangka panjang terutama bagi pemantapan konsolidasi demokrasi. Diharapkan perdebatan dalam penyusunan revisi UU Pilpres 2009 tidak mengulang pada perdebatan saat pengesahan UU Pilpres
2004 yang megutak-atik persyaratan calon dan jumlah prosentasi suara parpol pengusung calon.

Perdebatan menyangkut undangundang pilpres ini bisa menjadi bermutu, apabila menyentuh substansi seperti itu. Misalnya, aspek-aspek apa saja yang masuk ke visi dan misi? Apakah diperlukan apa yang disebut sebagai program seratus hari? Bagaimana menjanjikan visi dan misi itu kepada pemilih, supaya seluruh pemilih tahu bahwa presiden dan wakil presiden yang mereka pilih bekerja berdasarkan visi dan misi itu? Juga bagaimana partai politik ikut bertanggung jawab atas capres-cawapres yang mereka usung, bukan lantas cuci tangan. Lalu ada mekanisme koalisi permanan dalam menjalankan roda pemerintahan agar presiden selalu disokong oleh partai pengusungnya hingga berakhir masa kekuasaannya.

\section{Desain Dahulukan Pilpres dari Pileg 2009}

Agar Pilpres 2009 koheren dengan penguatan sistem presidensial dan berujung ada pemantapan konsolidasi demokrasi maka, perlu pula dipikirkan bangunan pemerintahan koalisi pas terbatas (minimalwinning coalition) yang permanen dan disiplin. Sebagai legal engineering, penting didorong agar pencalonan presiden dan pelaksanaannya dilakukan sebelum pemilu legislatif. Dengan demikian, partai-partai dirangsang berkoalisi karena platform perjuangan, bukan karena kepentingan kekuasaan (Denny Indrayana:2008).

Gagasan mendahulukan Pilpres dari pemilu legislatif adalah agar stabilitas politik lebih terjaga. Kiblat politisi masih ke Istana. Partai-partai politik yang berlaga dalam pemilu legislatif akan menyesuaikan diri dengan presiden terpilih, atau sebaliknya. 
Sinergitas Pemilihan Presiden 2009...; Agus Riewanto

Jika partai politik pendukung presiden dan wakil presiden yang sedang menjabat itu kalah tidak dengan sendirinya akan mengurangi legitimasi pemerintah. Karena selangkah lebih di depan, sejumlah negosiasi politik bisa saja ditempuh, termasuk mengorbankan program dan kebijakan tertentu atau mengubah komposisi kabinet.

Di samping itu, pemilih akan lebih mudah memahami ada dua lembaga yang dipilih, yakni eksekutif dan legislatif. Masyarakat juga gampang memilah kinerja partai politik di parlemen dan kinerja eksekutif tanpa harus terjebak model kampanye yang meletakkan semua soal pada kinerja pemerintah.

Mendahulukan Pilpres juga berdampak pada program pemerintah. Tanpa GarisGaris Besar Haluan Negara, presiden dan wakil presiden terpilih bisa sesegera mungkin mengajukan rancangan undangundang tentang sistem pembangunan nasional berdasarkan visi-misi dalam kampanye. Undang-undang itu menjadi panduan pemerintahan.

Konsentrasi terhadap pelaksanaan visimisi juga lebih fokus dan jelas ketimbang melaksanakan pemilu legislatif lebih dulu lantas program partai politik ditumpangkan kepada kandidat presiden dan wakil presiden. Hal ini juga mengeliminasi partaipartai politik, seperti dalam Pemilu 2004, yang lebih mengusung calon presiden dalam pemilu legislatif ketimbang program kerja masing-masing seandainya berada di legislatif.

\section{Desain Mencerdaskan Pemilih Pilpres 2009}

Setahun menjelang pelaksanaan Pilpres 2009 adalah momentum tepat untuk mendesain agar elite politik dan pemangku kepentingan (stake holders) dalam Pilpres: KPU, Banwaslu, Pers, LSM dan kelompok kepentingan lainnya agar menyatukan isu Pilpres bukan berhenti pada tataran teknis Pilpres demokratis melainkan bergerak maju pada tataran mencerdaskan rakyat dan pemilih pada konteks perhatian pada kualitas calon presiden-wakil presiden dan tawaran program (visi-misi) bagi kesejahteraan rakyat.

Di negeri kita pemilih dalam pemilu masih berada pada tahap supporters (pemilih semu), yakni mereka yang ikut berpartisipasi dalam pemilu lebih didasarkan pada hajatan ritualitas yang wajib diikuti tanpa disertai dengan pemahaman akan maksud, tujuan, arti dan fungsi keikutsertaanya,sehingga pemilih pada tahap supporters ini pada umumnya memiliki ciri-ciri negatif (Agus Riewanto: 2008):

Pertama, loyalis-sentimentil: pilihan politiknya pada partai politik atau orang tertentu, disebabkan oleh faktor pertimbangan naturalitas (budaya) dan idiologis. Kedua, emosional-irasional, yakni dalam melakukan pilihan politiknya cenderung didasarkan pada ikatan emosional, tanpa pikiran kritis akan untung dan rugi terhadap pilihannya.

Ketiga, pengabdian: pilihan politik dilakukan karena sebagai bagian rasa hormat, kepatuhan, ewuh-pakewuh dan sungkan. Keempat, hirarki: sandaran pilihan politik didasarkan pada beberapa fariabel, misalnya: faktor penampilan fisik (ganteng, pandai berorasi dan bernyanyi), aspek popularitas, status sosial, sumberdaya ekonomi, pendidikan dan mungkin garis keturunan (kasta) seorang calon di tengah masyarakat. Kelima, dukungan: melakukan pilihan hanya sekedar sebagai bentuk dukungan saja, tanpa disertai dengan embelembel kepentingan politik jangka panjang. 
UNISIA, Vol. XXXI No. 70 Desember 2008

Keenam, mobilisasi: turut serta dalam suatu pilihan politik karena dimobilisasi oleh elit politik lokal, tokoh masyarakat dan agamawan untuk memilih calon tertentu, dengan imbalan material, misalnya: sejumlah uang, kaos, kupon bensin, dan lainlain. Ketujuh, marah: pilihan politik hanya disebabkan pada kekecewaan terhadap calon lain, sehingga pilihan politiknya terpaksa dijatuhkan pada calon yang relatif tak membuat kecewa meskipun calon tersebut tak cukup memiliki tingkat kapabilitas yang diharapkan.

\section{Bagaimana Mendesain Pemilih dalam Pilres 2009 Menjadi Voters (pemilih yang sesungguhnya) Bukan sup- porters (Pemilih yang Semu)?}

Menurut Chaterine Barner (2001) model mencerdaskan pemilih dapat dilakukan melalui tiga tahap. Pertama, voters information: pendidikan pemilih lebih hanya ke arah informasi teknis pemilu, misalnya tata cara pencoblosan, tempat, tanggal memilih dan syarat-syarat pemilih. Kedua, voters education: pemberdayaan pemilih telah memasuki tahap-tahap filosofis, sosiologis, psikologis dan arti penting suatu pemilu dan partisipasi publik dalam sistem demokrasi.

Ketiga, civic education: pemberdayaan publik sebagai entitas politik dengan mempertimbangkan hak-hak asasi warga negara dalam suatu sistem demokrasi. Tahap pemberdayaan ini tidak hanya terbatas pada soal-soal yang berkaitan dengan pemilu, tetapi memasuki pula ranah sistem politik secara menyeluruh yang mengarusutamakan tingginya partisipasi publik dalam semua kebijakan politik negara.

Tiga model pencerdasan pemilih ini harus dilakukan secara tepat, cermat, konsisten dan simultan di Jateng, jika kita hendak memujudkan pemilih Pilpres 2009 yang sesungguh (voters). Pengalaman dalam dua pemilu sebelumnya: Pemilu DPD, DPR/DPRD 2004, Pilpres 2004 dan Pilkada sepanjang 2005-2008 ini. Pola pencerdasan pemilih tidak simultan dan nyaris hanya pada tahap voters information. Hanya sebatas tata cara dan teknis pemilu. Peran itu pun lebih banyak dilakukan oleh penyelenggaraan pemilu (KPU) dan pengawas pemilu (Panwaslu). Padahal tugas ini mestinya juga dilakukan oleh institusi partai politik dan para politisi, sebagaimana dimaksud dalam ketentuan Pasal 7 UU No.31/2002 tentang Partai Politik.

Oleh karena itu, dalam Pilres 2009 mendatang model pencerdasan pemilih harus dilakukan secara simultan, melibatkan banyak pihak (stake holders) dan tidak hanya berhenti pada tahap voters information, tetapi meretas jalan pada penggugahan kesadaran publik (raising consciousness) akan makna Pilpres 2009 bagi perubahan nasibnya dan masa depan daerahnya.

\section{Desain Kontrak Politik dengan Capres}

Untuk memastikan program kerja setiap Capres rakyat perlu menuntut Capres untuk membuat kontrak politik. Gagasan kontrak politik dalam Pilpres ini diadaptasi dari ide filsuf Plato (428-347) dan disempurnakan oleh John Locke (1632-1704) Montesquieu (1689-1755). Yakni suatu objek persetujuan (object of an agreement) antara warga negara dan penguasa untuk wajib memenuhi hak-hak politik warga negara dan menjamin kesejahteraan sosial.

Dalam konteks Pilpres dapat diwujudkan dalam bentuk konkret: bebas dari kemiskinan, tersedianya lapangan 
pekerjaan, pendidikan murah dan berkualitas, pelayanan kesehatan yang prima dan sanggup memerintah dengan tidak korupsi dan transparan.

Kontrak politik dengan objek yang jelas dan terukur ini wajib dilakukan oleh siapa saja yang bakal berkompetisi dalam Pilpres agar bekerja tidak dengan cheque kosong dan tidak boleh ditelikungi dan dkhianati ketika terpilih menjadi pasangan presiden dan wakil presiden.

Kontrak politik semacam ini harus menjadi agenda publik agar demokrasi di dapat bermakna bagi perubahan nasib rakyat. Kontrak politik semacam ini teramat urgen, jika kita menghendaki Pilpres 2009 mendatang menjadi berkualitas bukan hanya dalam arti prosedurnya yang demokratis, tetapi juga out put-nya berhasil memiliki presiden yang membawa dampak perubahan signifikan bagi publik.

Agar kontrak politik ini dapat mengikat kedua belah pihak, maka sudah semestinya dirancang dalam format hukum perdata yang tepat dan benar. Dengan dibubuhi tanda tangan, materai dan di depan Notaris. Ini semata-mata agar tidak menjadi dokumen politik belaka, melainkan menjadi dokumen hukum yang jelas tanggung-gugatnya antara Capres dan rakyat dan tidak dianggap remeh. Kontrak politik ini diharapkan bersifat praktis, konkret dan terukur untuk dikerjakan Capres.

\section{Desain Model Kampanye Pilpres 2009 yang Mencerdaskan}

Yang menonjol dari kampanye Pilpres 2004 adalah pada upaya mobilisasi massa, arak-arakan massa dengan raungan kendaraan bermotor tak jarang menggunakan anak-anak di bawah umur sebagai maskot, mendatangkan artis-artis ibu kota, bagi-bagi kupon bensin, aneka makanan, uang partisipasi, kaos dan lain-lain. Pola ini nyaris melupakan esensi kampanye, yakni untuk melihat dan menilai program kerja yang ditawarkan Capres.

Kampanye seperti ini, adalah model kampanye tradisional dan untuk Pilpres 2009 sudah harus ditinggalkan berganti dengan kampanye modern, yakni kampanye yang dilakukan para calon langsung maupun melalui juru kampanyenya (Jurkam) dengan cara meminimalir mobilisasi massa, memperkuat basis konstituen politik berdasarkan tawaran program dan penguatan sensitivitas terhadap isu-isu lokal, harian dan sederhana yang dibutuhkan publik ( Fritz Plasser and Gunda Plasser, 2002).

Kampanye modern ini relatif efektif dalam merebut hati pemilih, berbiaya murah dan lekat dalam ingatan publik. Sehingga kampanye modern ini cenderung dapat mendogkrak kecerdasan publik dalam politik dan terutama dalam menilai program dan rekam jejak calon (track record) baik kapasitas intelektual maupun moral. dan yang lebih penting kampanye model ini cenderung damai dan tak mengundang konflik massa.

Kampanye tradisional sebagaimana dipraktekkan di negara-negara berkembang termasuk Indonesia ini, kurang efektif merebut hati pemilih, berbiaya mahal, tidak lekat dalam ingatan publik dan yang lebih berbahaya cenderung membodohi publik dan terbukanya konflik massa antar pendukung.

Dalam kampanye modern karena konstituen politiknya relatif "melek politik", biasanya dalam menawarkan program dan visi-misi calon mengunakan media-media modern seperti, elektronik, berupa televisi dan membuka mililing list dan website dan 
UNISIA, Vol. XXXI No. 70 Desember 2008

media cetak koran umum harian, mingguan dan bulanan serta jurnal-jurnal khusus. Bahkan untuk merancang jargon, isu, ikon dan program para calon dalam pemilu di negara modern tak jarang memanfaatkan para ahli komunikasi, periklanan dan konsultan khusus kampanye dengan biaya khusus pula. Kini bahkan di Amerika Serikat, misalnya kampanye telah menjadi industri tersendiri dan lahan pekerjaan baru yang menantang.

Berbeda dengan pemilu model tradisional yang karena konstituen politiknya cenderung "buta politik", maka pada umumnya dalam menawarkan program visimisi hanya memanfaatkan alat kampanye tradisional berupa: baliho, banner, pamflet, selebaran stiker dan kaos yang daya jangkaunya terbatas. Yang aneh aneka alat kampanye tradisional ini malah terkadang tak berisi program kerja calon melainkan hanya perkenalan diri dengan menampilkan foto calon, mohon doa restu, dan ucapan selamat datang.

\section{Desain Menegemen Daftar Pemilih Tetap (DPT) Pilpres 2009}

Beberapa problem tentang Daftar Pemilih Tetap (DPT) yang terjadi pada Pilpres 2004 yakni:pemilih tidak terdaftar, daftar pemilih ganda, pemilih fiktif, pemilih di bawah usia, pemilih berstatus TNI/Polri dan pemilih meninggal dunia. Diharapkan tidak lagi terjadi pada Pilpres mendatang, sehingga tidak terjadi lagi tudingan penyelenggara Pilpres melakukan dugaan penggelembungan dan pengurangan suara Capres tertentu yang berujung pada gugatan hukum hasil suara pilkada di pengadilan.

Masalah-masalah tersebut, dilatarbelakangi oleh tidak akuratnya administrasi kependudukan dan pemilih. Sebagaimana diatur dalam UU No.23/2003 tentang Pilpres Pasal 20, DPT Pemilu Legislatif 2004 adalah DPT yang digunakan dalam Pilpres 2004 setelah diperbaharui. Mekanisme ini diadopsi dalam UU Pilpres 2009 lalu, sedangkan berdasar ketentuan dalam UU Pemilu Legislatif 2009 yang disyahkan beberapa waktu yang lalu DP4 (Daftar Penduduk Potensial Pemilih Pemilu) disiapkan oleh Depdagri.

Rencananya pada 5 April 2008 Depdagri menyerahkan pada KPU untuk dijadikan bahan penetapan DPT Pemilu legislatif dan Pilpres 2009 setelah dilakukan validitas di lapangan oleh Penyelenggara pemilu, sebagaimana diatur dalam ketentuan Pasal 19 Ayat (1) dan (4) PP No. 6 Tahun 2005 juncto Pasal 9 Ayat (2) huruf (d) dan Pasal 47 huruf (a), (c), (d), (e), (f), (g), (h), UU No. 22 Tahun 2007 tentang Penyelenggara Pemilu.

Sesuai alur yang dimaksud dalam ketentuan UU Pemilu 2004 itu bahan baku penetapan daftar pemilih oleh KPU berupa DP4 diperoleh dari Badan Pusat Statistik (BPS) melalui P4B (Pendaftaran Pemilih dan Penduduk Berkelanjutan). Lalu oleh KPU diserahkan pada KPUD Propinsi/Kabupaten/ Kota untuk kemudian ditetapkan menjadi Daftar Pemilih Sementara (DPS), diumumkan, dibuka Daftar Pemilih Tambahan (DP Tambahan) diumumkan kembali dan kemudian ditetapkan menjadi Daftar Pemilih Tetap (DPT). Masing-masing tahapan secara yuridis diberi tenggat waktu 3 (tiga) hari. Oleh karena itu, semua tahapan penyusunan daftar pemilih dan penetapannya menjadi Daftar Pemilih Tetap (DPT) oleh KPUD membutuhkan waktu 18 (delapan belas) hari.

Pendeknya tenggat waktu yang diberikan oleh UU kepada KPUD dalam menyusun dan menetapkan DPT itulah salah satu sebab 
Sinergitas Pemilihan Presiden 2009...; Agus Riewanto

utama munculnya sejumlah konflik dalam daftar pemilih selama ini.

Oleh karena itu, upaya pencegahan dan antisipasi agar DPT tidak menjadi pintu masuk (entry point) konflik politik dan hukum dalam Pilpres 2009 mendatang perlu dilakukan. Ini perlu dilakukan semata-mata untuk melindungi dan memberikan jaminan dan kepastian hukum, bahwa seluruh warga negara sipil yang telah berumur 17 dan atau kurang namun pernah kawin terdaftar sebagai pemilih dalam DPT dan agar KPU tidak disalahfahami publik sebagai pendistorsi demokrasi dalam Pilpres.

Pertama, dalam jangka panjang perlu dilakukan revisi terhadap aneka produk UU Pemilu agar memberi tenggat waktu yang cukup dalam melakukan pendaftaran pemilih. Dalam jangka pendek KPU perlu membuka daftar pemilih susulan bagi pemilih yang belum terdaftar, dalam hal ini KPU perlu mendesain peraturan sebagai petunjuk teknis pelaksanaannya. KPU perlu merancang desain regulasi agar tidak lagi menggunakan kartu pemilih sebagai bukti pemilih terdaftar, melainkan cukup dengan kartu tanpa penduduk (KTP) sepanjang nama pemilih terdaftar dalam DPT. Cara ini disamping dapat menghemat biaya pilpres, juga dapat memperpendek mata rantai birokrasi proses pemilihan di TPS.

Kedua, Depdagri mengolah data DP4 yang kelak diserahkan kepada KPU bukan semata-mata didasarkan pada data $\mathrm{P} 4 \mathrm{~B}$ dari BPS yang dilakukan pada tahun 2004 lalu melainkan pada data penduduk terkini. Karena itu, Depdagri perlu melakukan pemutakhiran dan validasi data pemilih pada pemilu terakhir jauh hari sebelum tahapan pemilu legislatif 2009 dimulai.

Ketiga, KPU perlu mengoptimalkan PPS di desa/kelurahan dalam proses pendaftaran pemilih. Tugas dan kewenangan
PPS untuk mengangkat Petugas Pendaftar dan Pencatat Pemilih (Gastarlih) agar dapat dapat menjangkau seluruh pemilih sampai di tingkat RT/RW. Tentu diperlukan seorang Gastarlih yang profesional dan mengerti demografi setiap daerah tugasnya. Bila dimungkinkan setiap TPS disediakan satu orang Gastarlih. Ini diperlukan agar tak satupun penduduk tercecer sebagai pemilih. Cara ini membutuhkan pengorbanan waktu yang cukup dan dana yang memadai.

Keempat, perlunya kesadaran penduduk untuk memastikan dirinya terdaftar sebagai pemilih dalam DPS dan DPT. Cara ini akan dapat memperingan tugas Gastarlih dalam proses pemutakhiran pemilih dan tidak selalu bergantung pada Gastarlih. Disamping juga dapat menjadi bukti, bahwa semua warga negara memiliki tanggungjawab dan mampu memperjuangkan hakhak politiknya sebagai sebagai pemilih dalam pilpres.

\section{Penutup}

Pemilihan presiden dan wakil presiden secara langsung 2004 adalah prestasi luar biasa yang diretas pasca tumbangnya rezim Orde Baru. la murupakan titik awal lahirnya harapan menyudahi transisi demokrasi menuju demokrasi sejati, bahkan kematangan demokrasi. Namun realitasnya, Pilpres untuk pertama kali ini belum berhasil mewujudkan impian rakyat terpilinnya presiden yang memakmurkannya. Ini disebabkan bukan hanya sifat pribadi presiden terpilih SBY-JK yang peragu dan tak tegas, namun juga konfliktualnya sistem pemerintahan yang dianut. Disatu sisi versi UUD 1945 pasca Amanden menganut sistem presidensial murni, namun dalam praktiknya menganut parlementer. Karena sistem presidensial berbalut dengan sistem multipartai di parlemen. Karena itu, sistem 
UNISIA, Vol. XXXI No. 70 Desember 2008

pemerintahan kita dewasa ini selalu tarik ulur antara executive heavy (1968-1998) ke legislative heavy (1998-2008).

Di titik ini diperlukan suatu sistem Pilpres yang koheren dan bersinergi dengan agenda pemantapan konsolidasi demokrasi, yakni sistem pemerintahan presidensial yang kuat dan efektif untuk menjadi kendaraan bagi percepatan kemakmuran rakyat. Ihtiar yang mungkin dilakukan adalah: (1) mendesain UU Pilpres 2009 yang elegan; (2) desain mendahulukan Pilpres 2009 dari Pileg 2009; (3) desain mencerdaskan pemilih Pilpres 2009; (4) desain kontrak pilitik dengan Capres; (5) desain model kampanye Capres; (6) desain menegemen Daftar Pemilih Tetap (DPT) Pilpres 2009

\section{Daftar Pustaka}

Asshiddiqie, Jimly, 2005. Format Kelembagaan Negara dan Pergeseran Kekuasaan Dalam UUD 1945, Cet. Ke-2, (Yogyakarta: FH UII Press).

Agustino, Leo,2002. "Pemilihan Presiden Secara Langsung Untuk Indonesia", Analisis CSIS, No. 2, Tahun XXXI/ 2002.

Bourchier, David,1996. Lineages of Organicist Political Thought in Indonesia. Ph.D.Dissertation. (Melbourne : Department of Politics, Monash University).

Firiciada Azhari, Aidil,2005."Koherensi dan Efektivitas Sistem Ketatanegaraan Indonesia Menurut Amandemen UUD 1945", dalam Jurnal Politika, Volume 1, No.2 Agustus 2005.
Gaffar, Afan,2002. “Amandemen UUD 1945 dan Implikasinya Terhadap Perubahan Kelembagaan", dalam Riza Sihbudi dan Moch. Nurhasim (eds.), 2002, Amandemen Konstitusi dan Strategi Penyelesaian Krisis Politik Indonesia, (Jakarta : AIPI).

Huntington, Samuel P,1995). Gelombang Demokratisasi Ketiga, (Jakarta : Grafiti).

Indrayana, Denny, 2008. "Mendesain Presidensial”, Kolom Opini, Kompas, 17 Maret 2008.

Lipjhart, Arend, ed. 1992. Parliamentarism versus Presidential Government (Oxford: Oxford University Press)

Leo Wiratma, I Made,2002, "Mendung Menyelimuti Reformasi Konstitusi : April-Juni 2002", Analisis CSIS, Tahun XXXI/2002 No. 2.

Manan, Munafrizal, 2008. "Bandul Kekuasaan Negara", Koran Tempo, 26 Agustus 2008.

Plasser, Frietz and Plasser,2002. Gunda Global Political Campaigning .

Palma, Giuseppe di, 1997. Kiat Membangun Demokrasi: Sebuah Esai tentang Transisi Demokrasi, (Jakarta : Yayasan Sumber Agung).

Risalah Sidang BPUPKI-PPKI 29 Mei 1945 - 19 Agustus 1945. (Jakarta : Sekneg $\mathrm{RI}, 1992)$.

Riewanto, Agus, 2007a, Ensiklopedi Pemilu: Analisis Pemilu 2004 Menuju Agenda Pemilu 2009, (Yogjakarta: Fajar Pustaka). 
Sinergitas Pemilihan Presiden 2009...; Agus Riewanto

\section{-——-, Agus,2007b. "Menjegal Rekonsolidasi Orde Baru", Kolom Wacana, Suara Merdeka, 22 Mei 2007.}

, Agus. 2008c. "Mendesain Model Mencerdaskan Pemilih", Kolom Gagasan, Solopos, $\quad 31$ Januari 2008.

-, Agus. 2002d, "Pro-Kontra Pilpres Langsung 2004" Kolom Wacana, SuaraMerdeka, 16 Juli 2002.

, Agus 2007e. "Purifikasi Sistem Presidensial", Kolom Opini, Suara Karya, 9 April 2007.

-, Agus 2008f. "Mencegah Daftar Pemilih Pemicu Konflik Pemilu", Kolom Opini, Wawasan, 13 Maret 2008

, Agus 2008g. "Peta Potensi Konflik Pemilu", Kolom Opini, Joglosemar, 27 Maret 2008

Agus 2008h. "Kontrak Politik dalam Pilgub Jateng", Kolom Forum, Kompas Edisi Jateng, 17 November 2008.

Stepan, Alfred, 1993. "Berbagai Jalur Menuju Demokratisasi : Sejumlah Pertimbangan Teoritis dan Komparatif”, dalam Guillermo O'Donnell, Philippe C. Schmitter and Laurence
Whitehead (eds.), 1993, Transisi Menuju Demokrasi: Tinjauan Berbagai Perspektif, (Jakarta : LP3ES).

Schedler, Andreas. 1998. "What is Democratic Consolidation?", Journal of Democracy, No. 2.

Surbakti, Ramlan.2002. "Perubahan UUD 1945 Dalam Perspektif Politik", dalam Riza Sihbudi dan Moch. Nurhasim (eds.), 2002, Amandemen Konstitusi dan Strategi Penyelesaian Krisis Politik Indonesia,Jakarta : AIPI.

Simanjuntak, Marsilam.1994. Pandangan Negara Integralistik. Jakarta : Grafiti.

Strong, CF. 1952, Modern Political Constitutions, London : Sidgwick \& Jackson.

Whitehead, Laurence, 1989, "The Consolidation of Fragile Democracy", dalam Robert Pastor (ed.), Democracy in the Americas, New York : Holmes.

Yudha AR, Hanta. 2008. "Proyek Stabilitas Politik", Media Indonesia, 4 Maret 2008.

SK KPU SK No 1151/15/VII/2004, tentang Sahnya Coblos Tembus.

Kompas, 7 Juni 2006 dan Kompas, 27 Juli 2004. 